\title{
Distribution and exploitation of manatees in Sierra Leone
}

\author{
Randall R. Reeves, Daphne Tuboku-Metzger and Richard A. Kapindi
}

West African manatees are believed to be declining over much of their range, including in Sierra Leone. They are nominally protected there, but they are traditionally caught and eaten because of their delicious meat and also because they are considered as pests by rice growers and fishermen. The authors' surveys in 1986-1987 showed that manatees are still widely distributed in coastal districts of the country, but that they are being regularly caught in some places, at levels that may not be sustainable. Much more needs to be known to guide appropriate action to ensure that the manatee remains a part of Sierra Leone's wildlife. It is encouraging that one of the authors has begun, under the government Fisheries Division, to implement a manatee research programme.

The West African manatee Trichechus senegalensis inhabits rivers, estuaries, swamps and some lakes along the west coast of Africa from the Sénégal River in the north to the Cuanza River of Angola in the south (Hatt, 1934; Husar, 1978; Nishiwaki et al., 1982). Although it is listed as threatened by the US (Cook, 1979) and vulnerable by the International Union for Conservation of Nature and Natural Resources (Anon., 1978), there is little quantitative documentation of the animal's past or present abundance in any part of its range. Like other sirenians, the West African manatee has long been hunted and trapped for meat, and its low reproductive rate makes it particularly vulnerable to over-exploitation. The species' long-term decline in many areas is believed to have been caused principally by subsistence hunting and the modification and destruction of habitat (e.g. Derscheid, 1926; Allen, 1942; Poche, 1973; Sikes, 1974; Nishiwaki et al., 1982; Powell, 1985; Roth and Waitkuwait, 1986). The manatee is nominally protected in most African countries where it occurs but, apart from the protection received within national parks, such as Parc national du Djoudj and Parc national du delta du Saloum in Sénégal (Maigret, 1982), there appears to be no meaningful enforcement.

Manatees in Sierra Leone
A few attempts have been made to observe and study West African manatees in their natural habitat (Sikes, 1974; Nishiwaki et al., 1982; Powell, 1986), but the animals' cryptic behaviour and the lack of water clarity have impeded these efforts. Nevertheless, Powell's recent radiotagging work in Ivory Coast shows promise.

Between November 1986 and May 1987 we conducted field surveys for manatees in three regions of Sierra Leone: the Great Scarcies and Little Scarcies rivers; the Sierra Leone River system near Freetown; and the upper portions of the Sherbro River system (Figure 1). We selected these areas because of statements in the literature that manatees had been trapped or hunted in them, or because employees of the government's Fisheries Division had personal knowledge of the manatee's occurrence and exploitation in them. We kept a careful watch for manatees while travelling on the rivers and spent a few hours drifting quietly or watching from the bank at places where local fishermen assured us that manatees were commonly seen. Most of our information, however, came from interviews with villagers, including the men who hunt, trap and net manatees. 


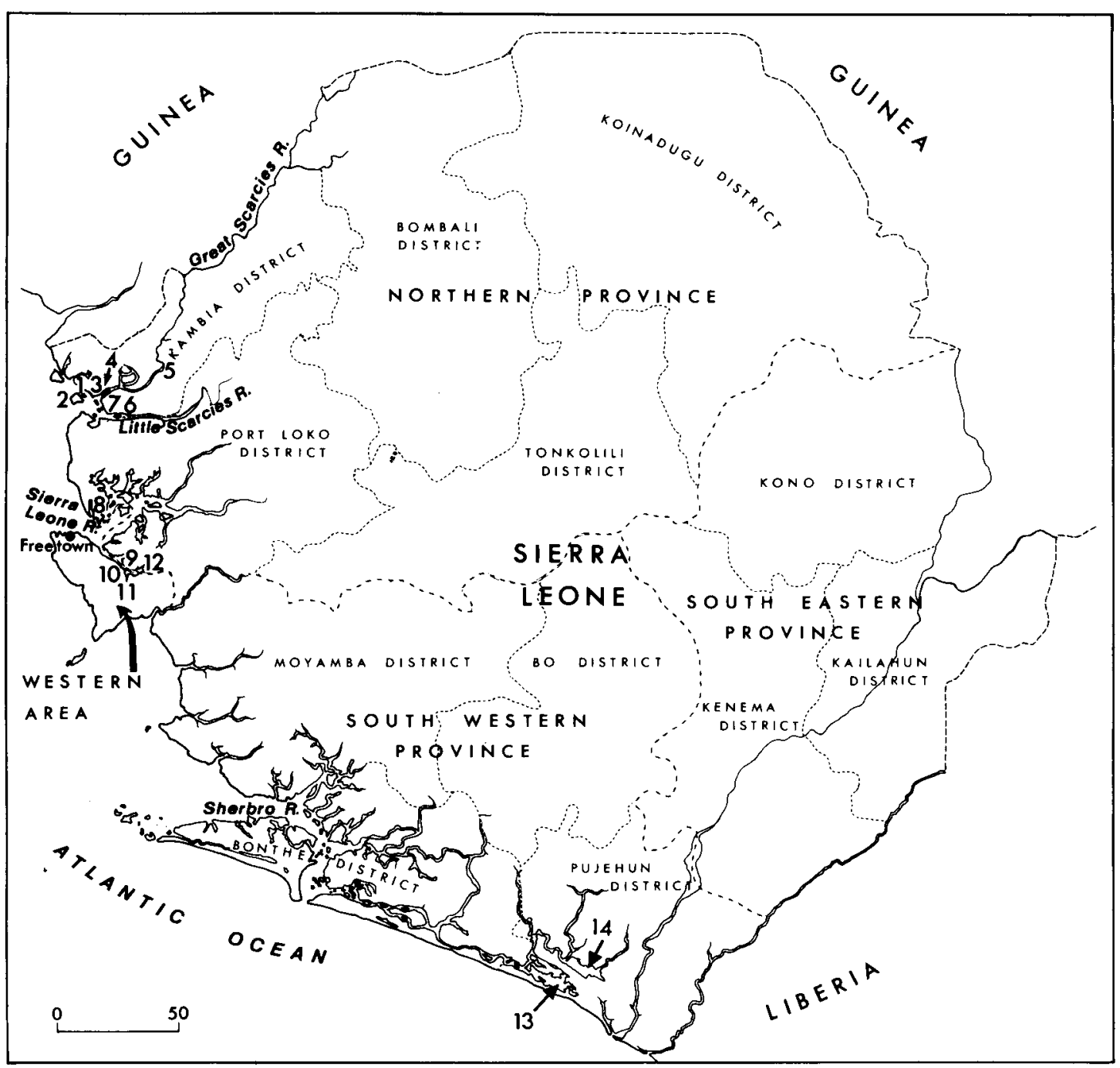

Figure 1. Map of Sierra Leone: (1) Yeligbungbo I, (2) Kortimaw I, (3) Balansera, (4) Rolal, (5) Rokupr, (6) Tenol, (7) Tumbu, (8) Rogberay, (9) Bunce R., (10) Susu Town, (11) Waterloo, (12) Pa Lokko, (13) Lake Mape, (14) Lake Mabesi.

\section{Previous knowledge of manatees in Sierra Leone}

Although it had long been known that manatees were present and exploited in Sierra Leone (Hatt, 1934), Hill's (1963) assessment of their status there was the first of any consequence. After a three-week visit to Sierra Leone he concluded that manatees were present throughout the coastal portions of the Bonthe and Pujehun districts. He also claimed that manatee numbers had 76 been 'considerably reduced by farmers and fishermen who caught them in wire fences in the fishing grounds, one fisherman alone catching over 50 in the 1960 "season"'. Morton (in Allsopp, 1969), Lowes (1970), Robinson (1971), Phillipson (1978) and Husar (1978) made passing reference to the manatee's occurrence and exploitation in Sierra Leone. Cole and Okera (1976) reported the capture of a manatee in 1973 in the upper Sierra Leone River estuary (Figure 2) and summarized three additional unconfirmed Oryx Vol 22 No 2, April 1988 


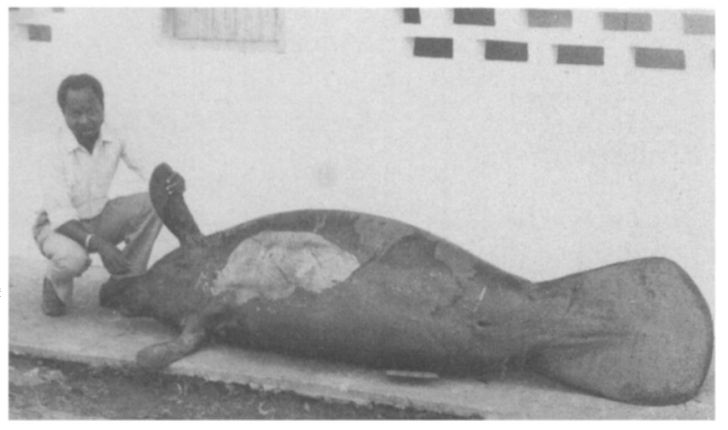

Figure 2. A 2.43-m female manatee taken in a trawl net in the upper Sierra Leone River estuary, 9 December 1973 (J. Amold Cole).

records. They aiso referred to reports of manatees eating and destroying rice planted in the cleared mangrove swamps, and of villagers setting manatee traps for the dual purpose of reducing crop damage and obtaining the animals' highly palatable meat. Most of these reports apparently came from the Sherbro River system in southern Sierra Leone.

\section{Distribution}

Our new information about the manatee's distribution is based on the distribution of traps and nets, and on information supplied by villagers.

\section{Great Scarcies and Little Scarcies rivers}

In this region most manatees are caught along mangrove shorelines near the mouths of the two large rivers. The area around Kortimaw and Yeligbungbo islands must have contained a substantial manatee population in the recent past, judging from catches made there by the people of Balansera (see below). Villagers claim that manatees are present as far up the Great Scarcies as Rokupr. In the Little Scarcies, most manatee hunting seems to be centred on Tenol.

\section{Sierra Leone river system}

Trappers from the villages of Waterloo, Pa Lokko and Susu Town catch manatees near the head of the Bunce River. Also, villagers told us of recent observations at a creek mouth near Rogberay on the north side of the Sierra Leone River.

Manatees in Sierra Leone

\section{Sherbro river system}

Manatees appear to be very widely distributed in the Sherbro River system (Figure 3). They ascend the Malen River to at least Shenge. We were told that they are sometimes caught at Semabu and Gangama, in swamps distant from the river's main channel. In the Waanje River they may ascend as far as Teboh, where the substrate becomes rocky. The people at Mabompa claim that manatees are often seen during the dry season (around March) at the junction of the Waanje and Sewa rivers. Although our survey did not include any part of the Sewa, we were told that manatees go up it as far as Tormabum.

The distribution of manatee traps and nets in Pujehun and Bonthe districts is indicated on Figure 3. Manatee ribs were shown to us in Gbundapi, Batahoi, Vaama and Saama, and in Vaama we were also given a fragment of the skull of a manatee, which had been taken in a net and eaten on 1 December, two days before our arrival.

We were disappointed not to be able to survey lakes Mape and Mabesi (Figure 1). Phillipson (1978) recommended at least one of these lakes

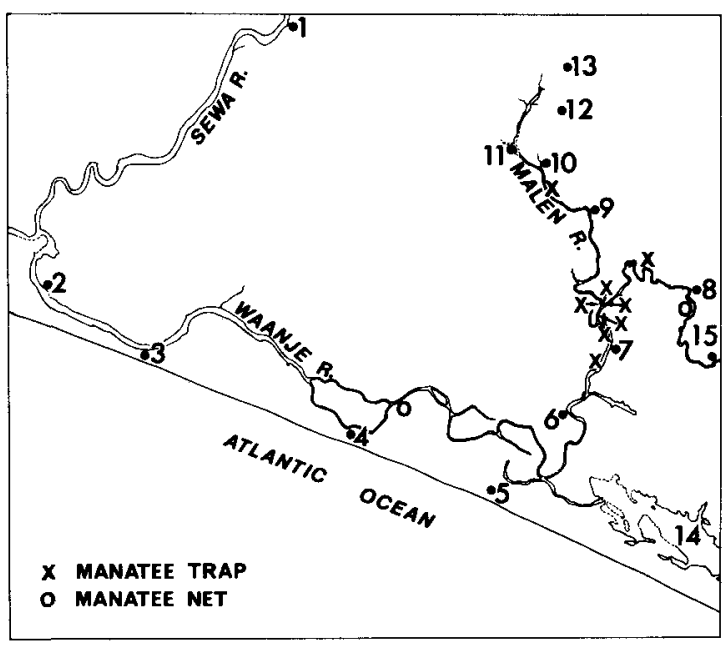

Figure 3. Map of the Sherbro River system: (1) Tormabum, (2) Mabompa, (3) Mano Kuranko, (4) Panguma, (5) Bengani,

(6) Saama, (7) Mopalma, (8) Vaama, (9) Gbundapi, (10) Batahoi, (11) Shenge, (12) Semabu, (13) Gangama,

(14) Lake Mape,

(15) Teboh. 
for national park status, noting that their fauna included 'many birds and animals, especially manatee and crocodiles'. He also cited the presence there of manatees as one reason to recommend game reserve status for a portion of Kpaka chiefdom, immediately east of the lakes. Phillipson did not visit Pujehun District and made his recommendations on the basis of information supplied by others. Some of the people we interviewed along the Waanje said they doubted that appreciable numbers of manatees inhabit the lakes, but the manatee trapper at Saama told us they do occur in Lake Mape at least.

All of our informants insisted that manatees are present in the main river channels year-round. However, a migration of some sort may take place, with an influx of new animals arriving in most upriver areas as flooding begins in June and July. The people far up the Waanje at Vaama insisted that groups of up to six manatees can be seen travelling 'in convoy' during the flood season; whereas no more than about two are seen at a time during the dry season.

\section{Exploitation}

\section{Catching methods}

The people we interviewed emphasized that most manatee captures take place in the rainy season (June-September). Various methods are used.

In Kambia District, we found three men who hunt manatees regularly with harpoons. They erect a platform in the mangrove forest and fence off a small, circular area beneath it, baited with mangrove fruits stuck into the soft mud. Two flexible sticks are implanted at the entrance to the enclosure, which faces the river. The harpooner, stationed on the platform, can tell by movement of these sticks when a manatee has entered the trap and, at an opportune moment, he thrusts the harpoon into the manatee's back. The harpooners claim supernatural spirits guide the manatees to the platforms, and they are reluctant to share information about their hunting activities.

Another method, used on Kortimaw and Yeligbungbo islands by men from Balansera, employs fence traps. A fence of sticks is erected between two mangrove trunks, with a door that opens towards the inside and lies flat on the mud. 78

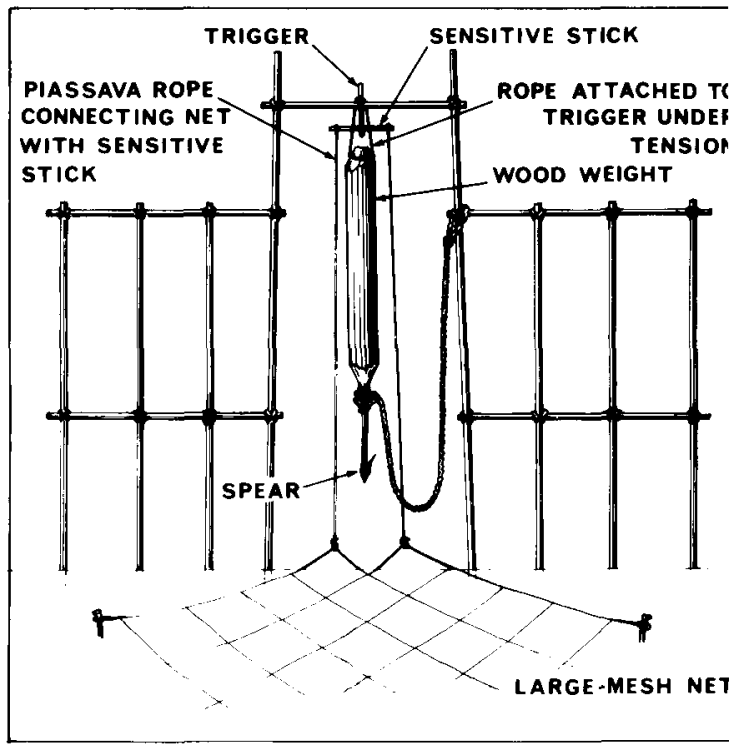

Figure 4. Diagram of a spear trap for manatees, as used in the Pujehun district (drawing by Laurie Schell).

Manatees move into the mangroves with the tide and, as the tide begins to ebb, a man stationed on a limb above the trap closes the door by pulling the attached rope, trapping the manatees in the mangroves. Some escape through alternative channels in the forest but the rest are killed with an axe at low tide. The fence traps are constructed in May and June, just at the beginning of the rainy season.

In the Bunce River manatees are trapped with nets. A chain net is placed well back from the main river channel amongst some mangrove bushes to seal off any escape routes. A second net is sited near the entrance of the channel into the mangroves, but it is not extended across the opening until the tide is high. Manatees, having come in with the high tide to feed on mangrove leaves, find all exits blocked when the tide goes out. Once stranded inside the trap, the manatees are killed by the trapper.

In Pujehun and Bonthe districts, manatees are caught in traps and nets. The traps (Figure 4) are set on routes frequented by manatees. Most are supported by posts driven into the ground, but some are rigged to trees. When a manatee presses against the middle of the net at the base of the trap, the ropes suspended from the sensitive 
stick bend it and release the trigger. The heavy log causes the sharp spear to fall on the manatee with considerable force. Once this spear is embedded in its flesh, the manatee is tethered to the support post.

Manatee nets (Figure 5) are made of strong twine, with a mesh size large enough to admit the head and flippers, but not the body, of a medium-tolarge manatee. These are set across small watercourses leading away from the main channel of the river.

Although one hunter (of Liberian origin) on the Waanje claimed to shoot at manatees with his shotgun, we found no evidence that the Mende people of Pujehun and Bonthe districts shoot manatees. Few own firearms. Small harpoon heads were on sale in Gbundapi, but these are said to be used for spearing large fish, reptiles and possibly porpoises, from boats at sea.

In addition to direct trapping, netting and harpooning, manatees are caught incidentally in fishing gear.

\section{Escape from traps and nets}

Manatees occasionally survive encounters with the traps and nets. Considering the severity of the wound made by the trap spear, it is likely that most of the individuals that escape the traps, by dislodging the spear or breaking the rope, die. The rate of escape from manatee nets depends on the quality of the twine used. The net we examined in the water near Panguma was badly worn and frayed, being made of material scavenged from the coast. The owner said that manatees often break free from his net, and he lost three during the 1986 rainy season. Manatees that escape from encounters with nets do not necessarily survive. In Florida, pieces of net, rope or line left around flippers have been known to cause infections, sometimes leading to septicaemia and eventually death (Beusse et al., 1981; O'Shea et al., 1985). Flippers have been gradually severed by entangled line, impairing locomotion. Reproduction may be compromised if lactation from the axial teats is impaired (T.J. O'Shea, pers. comm., 4 March 1987).

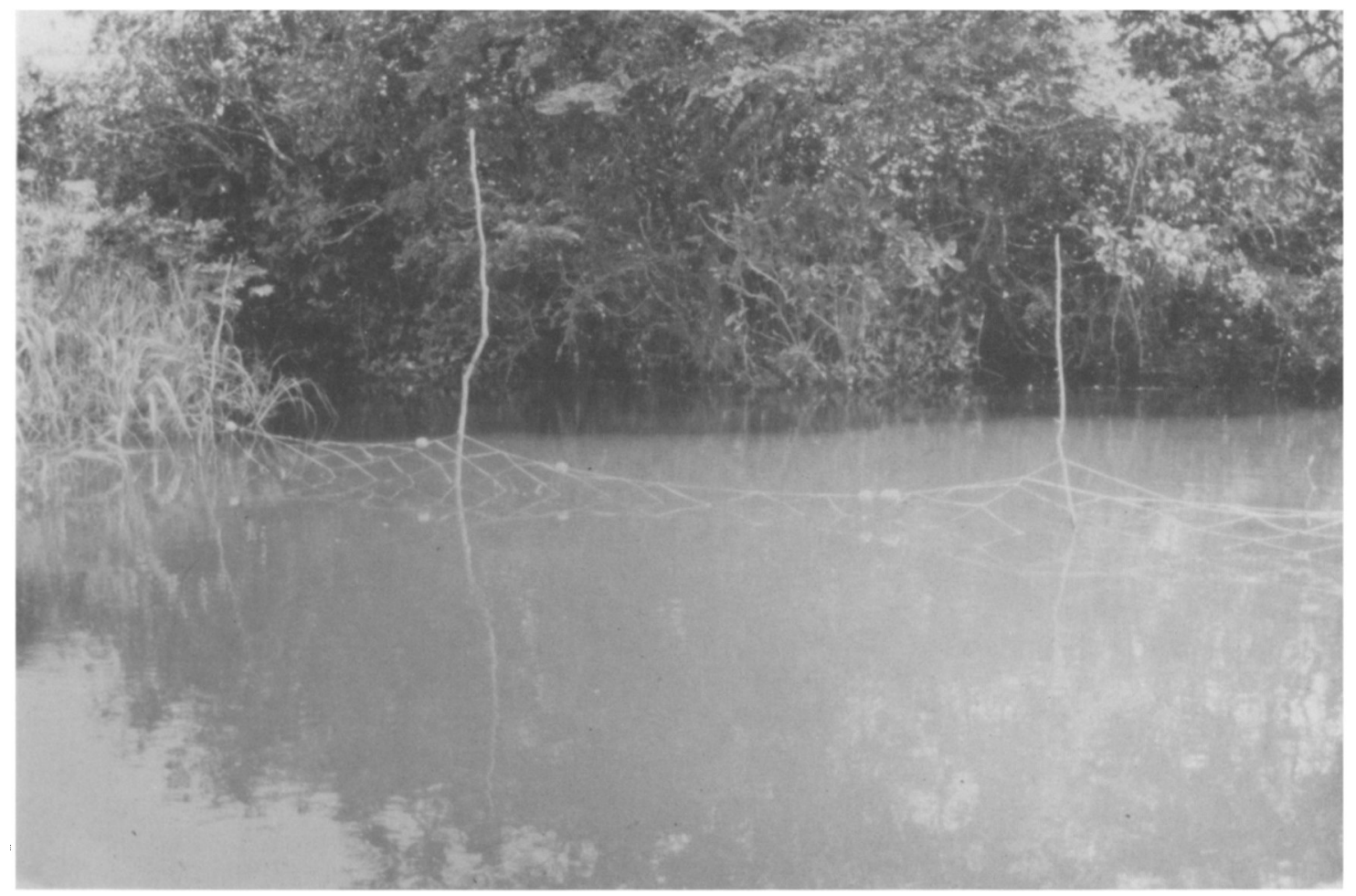

Figure 5. A manatee net set in the Waanje River near Vaama (R. Reeves). 


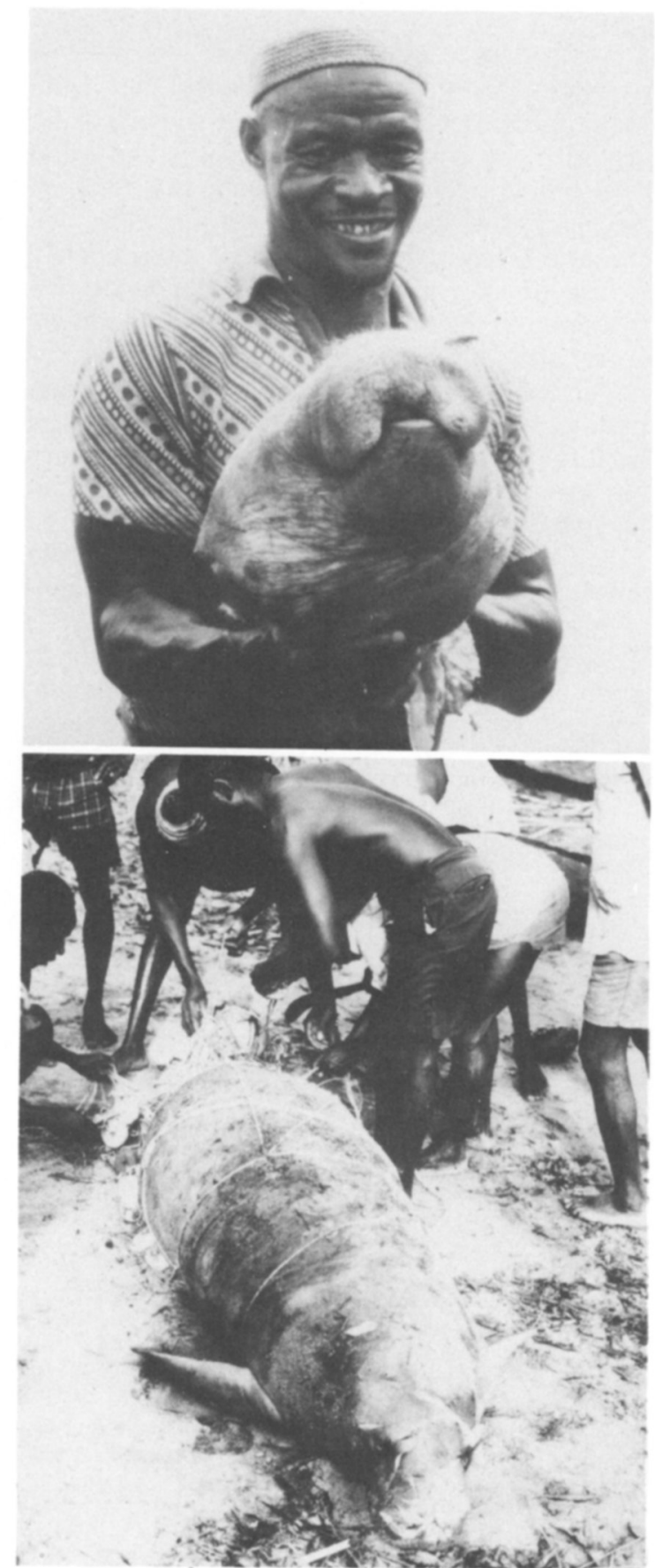

Figure 6. (Tio) Head of a butchered manatee at Gbandakor, Malen River, April 1982 (bottom); removing a manatee from a net at Mano Kuranko, Waanje River, February 1983 (Harry Spaling).

\section{Utilization of carcasses}

Villagers consume virtually the entire manatee. The only parts that seem to remain intact after butchering are the hard, heavy ribs. Manatee bone is sometimes carved to make handles for walking sticks or spinning-tops used in a local game called cii (in Mende). There appears to be no commercial market for these products. We found no evidence that the manatee's skin is used for medical or therapeutic purposes as it is in Nigeria (Reeves, unpub. data).

In the south, the meat is customarily shared among the villagers (Figure 6). Any that remains can then be sold by the trapper, netter or hunter. No one seems to make much money, however. The most reported to us was 200 Leones ( 30 Leones = 1 US dollar in late 1986) received by a man in Gbundapi who caught a manatee in a draw-chain net in early 1986. Trappers told us that many of the manatees they catch yield no profit, as the entire carcass gets distributed within the village.

In Kambia District at Rolal, the first manatee caught each season is shared freely among the villagers, and the tail is given to the paramount chief. Manatees caught subsequently are sold by the slice, a large slice costing 8 Leones, a small one 4 Leones. The average value of an entire manatee is said to be about 600 Leones ( $=20$ US dollars).

\section{Catch statistics}

Under tribal law, in at least the southern districts, the capture of a manatee must be reported to the section chief so that he can collect his share of the meat. In spite of this custom, records do not seem to have been kept of the numbers killed in any area. The government Fisheries Division has not collected manatee catch statistics in the past. However, R. Kapindi was recently designated the Fisheries Division's manatee co-ordinator, and he has begun to implement a research programme that will include harvest monitoring. The information shown in Table 1 , derived primarily from interviews, is certainly incomplete and can only be taken as a preliminary indication of the levels of effort and catch in the areas we surveyed. Our coverage did not include all the villages where manatees are trapped, netted or hunted.

Oryx Vol 22 No 2, April 1988 
Table 1. Information on the capture of manatees in Sierra Leone

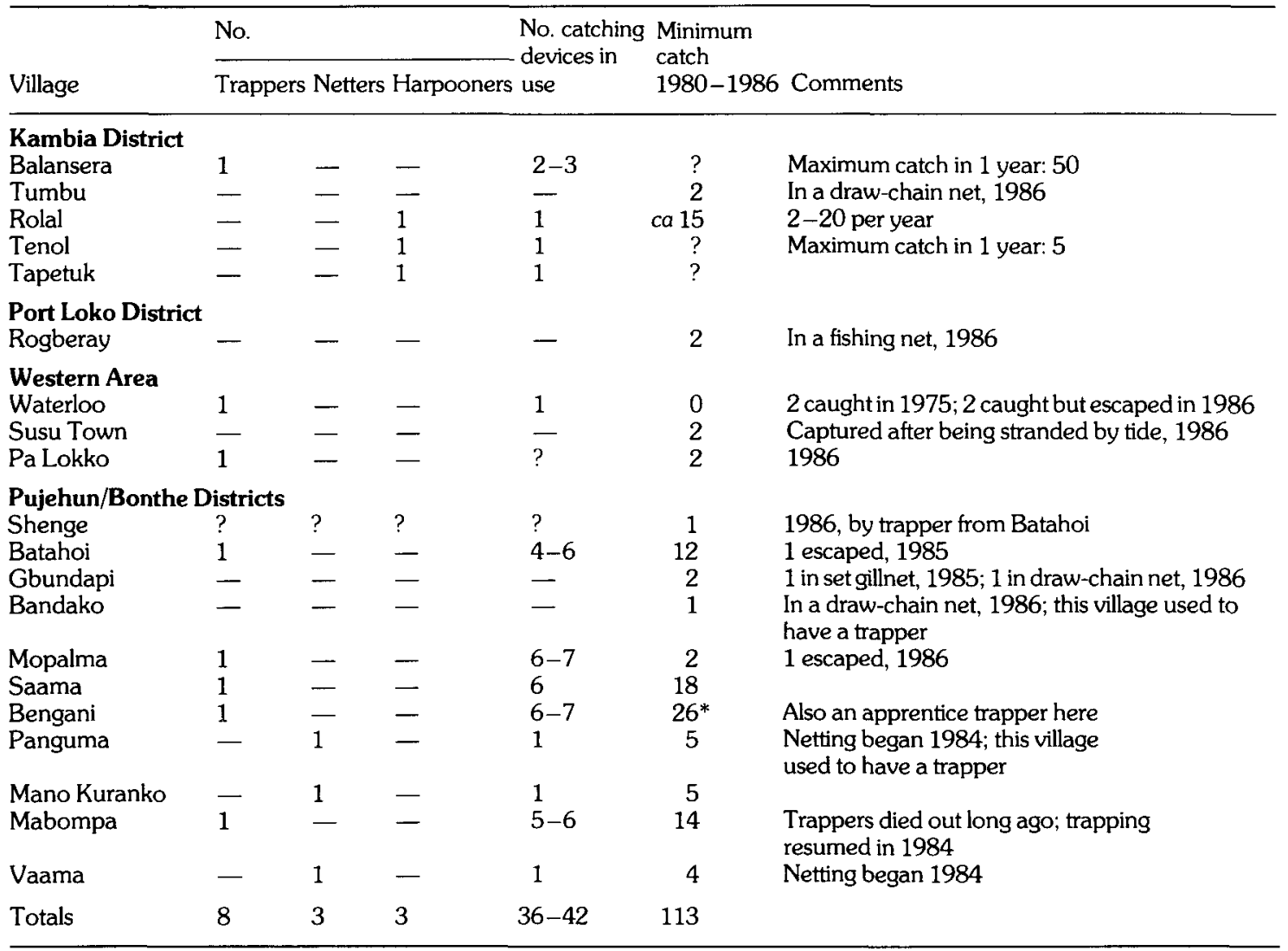

*One of these escaped from the trap, bearing the spear, and was later found dead in another chiefdom downriver.

\section{Conflicts with fishing and farming}

Fishermen in Pujehun and Bonthe districts complain bitterly about the damage caused to their gillnets by manatees. The problem of manatees colliding with nets has another side, of course, in that those caught provide tasty, valuable meat.

Manatees are primarily herbivores. The West African species is known to feed on aquatic vascular plants (including Cymodocea nodosa, Polygonum sp., Eichomia crassipes and Vossia sp.) as well as the leaves of mangroves (Rhizophora sp.) hanging over the water's edge (Husar, 1978). It is thus somewhat surprising that fishermen in Sierra Leone frequently complain of manatees removing fish from gillnets. Other than the villagers' graphic descriptions of how the manatees 'suck' the fleshy parts from the fish and Manatees in Sierra Leone leave the head, bones and sometimes the skin still attached to the netting, we obtained no tangible evidence of net-robbing. However, the subject was always raised by the fishermen themselves, in response to the question: 'What do manatees eat?'. Their descriptions closely resembled those reported by Powell (1978) for Jamaica, involving West Indian manatees Trichechus manatus. Besides fish, manatees in southern Sierra Leone are said to eat mainly elephant grass Pennisetum purpureum and rice; in the northern districts, the leaves and fruits of mangroves are considered important as well. No one in the river villages seems to doubt that manatees eat large quantities of rice, but this food preference requires better documentation.

As was noted by Hill (1963) and Cole and Okera (1976), rice farmers consider manatees to be 
serious pests. Thus, the fishermen/farmers who capture them are seen as performing an important service to the community. The people of a village where no one regularly catches manatees sometimes invite a trapper from another village to set his traps in, or near, their fishing grounds and rice fields. Under such an arrangement the people of this village get shares of the meat from any manatee caught, and the trapper then sells what is left over. Several villages that have no trapper or netter expressed a keen desire to employ one.

\section{The future of manatee exploitation in Sierra Leone}

Many of the manatee hunters and trappers are old men. The trapper at Batahoi is about 60-70 years old. He estimates that he has caught more than 200 manatees in his 50-year career, and up to 10 in a single rainy season. A trapper at Saama is about 80 years old and has been trapping for about 60 years. The best year he can remember was about 1980, when he caught 15 manatees near Mabompa. In contrast to these two, the old (about 80 years) manatee trapper at Mopalma

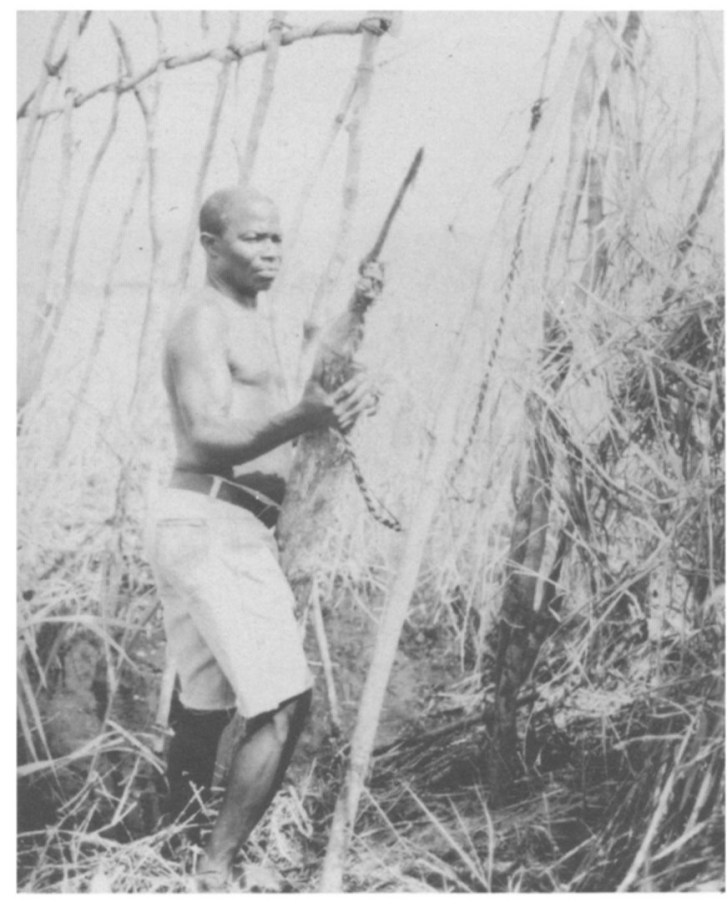

While some trappers shoot manatees, nets and traps are the more usual methods. learned the trade late in life and told us that he ha: caught only six manatees.

Old as some trappers may be, manatee trappins is not a dying art. At least two of the active trap pers (at Mabompa and Bengani) are 40-50 year: old and still vigorous. One of them has a younc 'apprentice'. At least one other young man whi recently learned how to trap manatees is said tc be active in the Pujehun District.

The villagers at Batahoi maintain that manatee: have been trapped there, in the same manner, fo at least 100 years. They also claim the trappin! pressure is presently the same as, or less than, $\mathrm{i}$ was in the past, and that manatees are at least a: abundant as they ever were. Similar claims werk made in most of the areas we visited. An excep tion was the trapper in Balansera, who admittec that his catch has declined and that manatee: seem to be less abundant locally than they were ir the past. The old (in his 60s) trapper at Waterloc maintained that, although manatees are still com mon in the area, fewer are caught nowaday: because the type of equipment needed for con structing the traps is not easily available.

\section{Manatee conservation in Sierra Leone}

The manatee was not protected under Sierr: Leone's Wild Animals, Birds and Fish Preser vation Ordinance of 1901, and it was not unti the early 1960s that the Committee for the Pre servation of Flora and Fauna recommended it: classification as an animal with a restricted rangt and thus particularly liable to extermination. The committee stressed that nothing was known o the manatee's past or current abundance anc habitat requirements-it probably needec protection and surveys should be undertaken tc assess the species's status. Hill (1963) furthe recommended that an area of the estuaries anc mangrove islands in the Bonthe District should be set aside to protect the manatee and othe: animals found there.

The Wild Life Conservation Act, signed into lau in January 1973, empowers the Minister of Agri culture, Natural Resources and Forestry tc declare areas as strict natural reserves, nationa parks, game reserves, or controlled huntins areas. In addition, chiefdom councils can, witt ministerial approval, designate game sanctuaries Oryx Vol 22 No 2, April $198 \varepsilon$ 
However, the plans for a manatee reserve in the Bonthe District noted by Lowes (1970) have not come to fruition.

The manatee is officially protected under the Wild Life Conservation Act, but this seems to have had no practical effect. Contrary to Husar's (1978) statement that in much of the West African manatee's range 'the impact of hunting is difficult to ascertain, because the animals are now mostly protected legally and hunting is done secretly', the catching of manatees and the distribution or selling of their meat is openly practised in Sierra Leone. This may reflect, in part, the failure of the central government to inform the populace of the wildlife law's provisions. But even if they knew it was technically illegal, villagers probably would continue to catch and consume manatees. $\mathrm{Be}$ cause Sierra Leone's 220 chiefdoms have considerable autonomy, tribal law governs much of day-to-day village life. Laws concerning the protection of wildlife are unlikely to have much effect unless they are endorsed by the paramount chief of the area.

In spite of the obvious potential threat of overexploitation, several factors seem to be working in favour of manatees in Sierra Leone. Their habitat appears to be little damaged as yet. There are no major dams in the Sherbro or Scarcies river systems, so the animals have unimpaired access to a vast network of waterways and swamps, particularly during the rainy season. There appears to be no significant industrial or chemical pollution in the rivers, although the effects of mining operations in some areas need to be studied. Cultivation of floating and swamp rice seems not to impair or reduce the available habitat, although it does create a serious conflict between farmers and manatees. There is human traffic on some rivers, particularly on market days, but most of it consists of hand-paddled dug-out canoes and the engine-driven boat 'buses', which move slowly and on a steady course.

Two agencies operate high-speed outboardmotor boats in the Pujehun and Bonthe districts. In 1986 the government's Fisheries Division had an $18-\mathrm{ft}(5.5-\mathrm{m})$ dingy with a $15-\mathrm{hp}$ engine stationed at Gbundapi (a second similar boat and engine were due to be delivered in March 1987). In addition, a North American mission and Manatees in Sierra Leone development group, Christian Extension Services, operates 11 speedboats: two 18 -ft and two $16-\mathrm{ft}(4.9-\mathrm{m})$ boats with $80-$ and $60-\mathrm{hp}$ engines, respectively, and seven $17-\mathrm{ft}(5.2-\mathrm{m})$ boats with 15-hp engines. These powered vessels rarely collide with manatees. However, in Florida, USA, collisions with boats are the most frequently documented cause of manatee mortality (O'Shea et al., 1985), and any increase in the number of power boats would increase the danger to these animals.

A more serious immediate threat to manatees in Sierra Leone may come from the expanding fisheries. The Federal Republic of Germany, through its aid agency Deutschegesellschaft für Technische Zusammenarbeit, is sponsoring major fishery development programmes in Pujehun District and in the Western Area south of Freetown. In addition to supplying launches and outboard motors to the Fisheries Division, the Bo-Pujehun and Tombo projects have provided technical training and gear to artisanal fishermen (e.g. see Beck and Forde, 1985). Synthetic-fibre netting and lines are available at affordable prices, and the fishing pressure has become locally intensive. Manatees frequently collide with the nets. Most probably survive such encounters, but some are caught and killed by entanglement in set gillnets. Also, when a fisherman is fortunate enough to trap a manatee in an actively fished net, the animal is promptly killed and distributed or sold.

\section{Summary and conclusions}

Our study of manatees and manatee exploitation in Sierra Leone has only begun. We have confirmed that manatees are still widely distributed in the coastal districts, and we suspect they occur at fairly high densities in some areas, at least seasonally. Also, we have identified sites where manatees are regularly trapped, netted and harpooned. The potential, therefore, exists for studying the West African manatee's biology, ecology and behaviour, and for conserving this species in Sierra Leone. Considering that much of Sierra Leone's diverse fauna has tragically declined in recent years (Robinson, 1971; Phillipson, 1978; Teleki, 1980; Teleki and Baldwin, 1981), progress in conserving manatees would be a welcome exception. We hope the government of Sierra Leone and the international scientific and 
conservation communities will be quick to take advantage of this opportunity, bearing in mind the manatee's significance in the culture and ecology of the farming and fishing people who share its habitat.

\section{Acknowledgments}

The work reported here was funded by the United Nations Environment Programme, the People's Trust for Endangered Species, and the US Marine Mammal Commission. We are grateful for the logistical support provided by the Sierra Leone Ministry of Agriculture, Natural Resources and Forestry, and by Christian Extension Services. For their individual cooperation, we thank Mohamed Souma, Harry Spaling, and Dirk and Joanne Booy. We are grateful to Mr Spaling and $\mathrm{J}$. Arnold Cole for allowing us to use their photographs, and to Rob Landis for assisting with the field trip to the Great Scarcies and Little Scarcies rivers. Laurie Schell prepared the maps and drawing. Thomas J. O'Shea, Daryl P. Domning, James A. Powell, Harry Spaling and an anonymous reviewer provided helpful comments on the manuscript.

\section{References}

Allen, G.M. 1942. Extinct and Vanishing Mammals of the Westem Hemisphere with the Marine Species of all the Oceans. Committee of International Wild Life Protection, Special Publication No. 11. Cooper Square Publishers, Inc., New York.

Allsopp, W.H.L. 1969. Aquatic weed control by manateesits prospects and problems. In Man-made Lakes-The Accra Symposium (ed. L.E. Obeng), pp. 344-351. Ghana University Press, Accra.

Anon. 1978. Red Data Book. Volume 1. Mammalia. Morges, Switzerland.

Beck, U. and Forde, A.C.V. 1985. Fisheries Pilot Project Tombo. Republic of Sierra Leone-Federal Republic of Germany. Promotion of small-scale fisheries in the Republic of Sierra Leone. Concept and strategy of the project. Paper presented at the FAO/CECAF Regional Workshop on Small-scale Fisheries Development and Management, Lomé, Togo, 20-29 November 1985.

Beusse, D.O., Jr, Asper, E.D. and Searles, S.W. 1981. Some causes of manatee mortality. In The West Indian Manatee in Florida. (eds R.L. Brownell, Jr and K. Ralls), pp. 98101. Proceedings of a workshop held in Orlando, Florida, 27-29 March 1978. Florida Department of Natural Resources, Tallahassee, Florida.

Cole, A. and Okera, W. 1976. Records of the West African manatee, Trichechus senegalensis Desm. in Sierra Leone. Bulletin of the Institute of Marine Biology \& Oceanography (Fourah Bay College, University of Sierra Leone), 1(1), 42-43.

Cook, R.S. 1979. Endangered and threatened wildlife and plants: final threatened status for West African manatee. US Federal Register, 44(141), 42910-42912.

Derscheid, J.M. 1926. Les lamantins du Congo (Trichechus senegalensis Desm.) avec notes sur la répartition geographique et l'extermination des siréniens. Rev. Zool. Afr. 14(3), 23-31.

Hatt, R.T. 1934. A manatee collected by the American 84
Museum Congo Expedition, with observations on the Recent manatees. Bulletin of the American Museum of Natural History, LXVI(IV),533-566.

Hill, P.R. 1963. FAO/IUCN African Special Project. Interim report by P.R. Hill, ASP III Consultant, on Sierra Leone, 13 March-2 April 1963.

Husar, S.L. 1978. Trichechus senegalensis. American Society of Mammalogists, Mammalian Species, 89, 1-3.

Lowes, R.H.G. 1970. Destruction in Sierra Leone. Oryx, 10, 309-310.

Maigret, J. 1982. Recherches scientifiques dans les parcs nationaux du Sénégal. XVIII. Les mammifères marins du Sénégal. Etat des observations dans les parcs nationaux. Memoires de l'Institut fondamental d'Afrique noire, IFANDakar, 92, 221-231.

Nishiwaki, M., Yamaguchi, M., Shokita, S., Uchida, S. and Kataoka, T. 1982. Recent survey on the distribution of the African manatee. Sci. Rep. Whales Res. Inst. 34, $137-147$.

O'Shea, T.J., Beck, C.A., Bonde, R.K., Kochman, H.I. and Odell, D.K. 1985. An analysis of manatee mortality patterns in Florida, 1976-81. J. Wildl. Manag. 49, 1-11.

Phillipson, J. 1978. Wildlife Conservation and Management in Sierra Leone. Prepared at the request of the Ministry of Agriculture and Natural Resources, Sierra Leone. The British Council.

Poche, R. 1973. Niger's threatened Park W. Oryx, 12, 216-222.

Powell, J.A. 1978. Evidence of camivory in manatees (Trichechus manatus). J. Mammal. 59, 442.

Powell, J.A. 1985. Status of the West African manatee in The Gambia, West Africa. Sixth Biennial Conference on the Biology of Marine Mammals, Vancouver, British Columbia, Canada, 22-26 November. Sponsored by The Society for Marine Mammalogy. [Abstract.]

Powell, J.A. 1986. Ivory Coast. Status and conservation of West African manatees. Sirenews, Newsletter of the IUCN/SSC Sirenia Specialist Group, 6, 7-8.

Robinson, P.T. 1971. Wildlife trends in Liberia and Sierra Leone. Oryx, 11, 117-122.

Roth, H.H. and Waitkuwait, E. 1986. Répartition et statut des grandes espèces de mammifères en Côte-d'lvoire. III. Lamantins. Mammalia, 50, 227-242.

Sikes, S. 1974. How to save the mermaids. Oryx, 12, $465-470$.

Teleki, G. 1980. Hunting and Trapping Wildlife in Sierra Leone: Aspects of Exploitation and Exportation. A report prepared for the Government of Sierra Leone. Sponsored by New York Zoological Society, World Wildlife FundUS, Fauna Preservation Society and D.A.C. van den Hoorn of De Telegraaf newspaper

Teleki, G. and Baldwin, L. 1981. Sierra Leone's wildlife legacy: options for survival. Zoonooz, LIV(10), 21-27.

Randall Reeves, Okapi Wildlife Associates, 27 Chandler Lane, RR 1, Box 1096, Hudson, Quebec JOP 1HO, Canada.

Daphne Tuboku-Metzger, Sierra Leone Environment and Nature Conservation Association, PMB 376, Freetown, Sierra Leone.

Richard A. Kapindi, Fisheries Division, Ministry of Agriculture, Natural Resources and Forestry, Youyi Building, Freetown, Sierra Leone. 